\title{
Cold-Rolling Strain Hardening Effect on the Microstructure, Serration-Flow Behaviour and Dislocation Density of Friction Stir Welded AA5083
}

\author{
Zainuddin Sajuri ${ }^{1, *}$, Nor Fazilah Mohamad Selamat ${ }^{1}$, Amir Hossein Baghdadi ${ }^{1, *}$, \\ Armin Rajabi ${ }^{1}$, Mohd Zaidi Omar ${ }^{1}{ }^{10}$, Amir Hossein Kokabi ${ }^{2}$ and Junaidi Syarif ${ }^{3}$
}

1 Department of Mechanical and Manufacturing Engineering, Faculty of Engineering and Built Environment, Universiti Kebangsaan Malaysia, Bangi 43600 UKM, Malaysia; norfazilah2468@gmail.com (N.F.M.S.); arminrajabi@gmail.com (A.R.); zaidiomar@ukm.edu.my (M.Z.O.)

2 Department of Materials Science and Engineering, Sharif University of Technology, Azadi Avenue, Tehran 145888-9694, Iran; kokabi@sharif.edu

3 Department of Mechanical and Nuclear Engineering, College of Engineering, University of Sharjah, Sharjah 27272, UAE; sjunaidi@sharjah.ac.ae

* Correspondence: zsajuri@ukm.edu.my (Z.S.); baghdadi.amirhossein@gmail.com (A.H.B.); Tel.: +60-(3)-8911 8017 (Z.S.)

Received: 26 November 2019; Accepted: 12 December 2019; Published: 2 January 2020 updates

\begin{abstract}
Al) alloy materials have extensive structural applications in transportation industries because of their high strength-to-weight ratio and corrosion resistance. However, under conventional fusion weldings, these materials are limited by their porosity, hot cracking, and distortion. Herein, friction stir welding (FSW) was performed to join a similar AA5083 alloy. A post-weld cold-rolling (PWCR) process was applied on joint samples at different thickness-reduction percentages (i.e., $10 \%, 20 \%$, and $40 \%$ ) to identify the effect of strain hardening on the microstructure and mechanical properties of the friction-stir-welded joint of AA5083 while considering the serration-flow behaviour at stress-strain curves and dislocation density of the post-weld cold-rolled (PWCRed) samples. FSW induced a $20 \%$ reduction in the tensile strength of the joint samples relative to the base metal. PWCR also reduced the average grain size at the nugget zone and base metal because of the increase in plastic deformation imposed on the samples. Furthermore, PWCR increased the dislocation density because of the interaction among dislocation stress fields. Consequently, the tensile strength of the friction-stir-welded joint increased with the increased cold-rolling percentage and peaked at $403 \mathrm{MPa}$ for PWCRed- $40 \%$, which significantly improved the serration-flow behaviour of stress-strain and welding efficiency up to $123 \%$.
\end{abstract}

Keywords: friction stir welding; post-weld cold-rolling; microstructure; mechanical properties; serration flow behaviour; dislocation density

\section{Introduction}

Aluminium (Al) alloys are exceptionally adaptable materials that are particularly appropriate for the development of structural designs associated with the transportation industry, given their high corrosion resistance, high toughness, and light weight [1,2]. AA5083 is a frequently utilised Al alloy in the 5xxx series. The versatility of this strain-hardened alloy renders it ideal for applications related to the automotive industry [3] and for the fabrication of marine structures, pipelines, and aircraft components [4]. Given the problems encountered in the fusion welding of $\mathrm{Al}$ alloys, such as porosity [5], cracking [6], and dissolution of precipitation phases [7,8], a solid joining technique known as friction stir welding (FSW) was carried out for the joining of Al alloys [9-13]. In 1991, this welding 
process was introduced by The Welding Institute [14]. FSW is a joining process involving the use of a rotating tool that plunges and traverses along the interface of two or more plates [15]. FSW is used in the aerospace, automotive, railway, and shipbuilding industries. It is typically applied to butt joints on large Al parts [16]. Several advantages, including high-quality joints, low-energy process, precise external control, low pollution, and lack of special sample preparation, are provided via FSW [17-19]. In FSW, the deformation of the material under melting-point temperatures reduces the negative effects caused by distortion and residual stress [20,21].

Although FSW is a solid-state welding process, it is susceptible to the effects of residual stress and distortion [22], which diminishes the joint's mechanical strength. The effect of residual stress in FSW has been extensively investigated. For example, Liu et al. [23] employed the neutron diffraction method to analyze residual stress in single- and double-sided friction-stir-welded (FSWed) Al 6005A-T6. The single-sided FSW of $6005 \mathrm{~A}-\mathrm{T} 6$ delivers a maximum tensile strength of $74.4 \%$ of base metal (BM) with low residual stresses of approximately $37.5 \%$ yield strength of $\mathrm{BM}$ and a peak yield strength extent of approximately $37.5 \%$. Furthermore, the double-sided FSW of 6005A-T6 shows a residual stress of $70 \%$ yield strength of BM with a tensile strength of $80.8 \%$ of $\mathrm{BM}$, which is double that derived through single-sided FSW.

The FSW of AA5083 has been widely investigated to optimise welding parameters and achieve the maximum joint strength [24-27]. Reduced mechanical properties still occur in AA5083 FSWed joints because of high solute concentration; the associated strain hardening; and the serration-flow behaviour effect (Portevin-Le Chatelier effect [28]) occurring in the microstructure of FSWed joint, especially at the heat affected zone (HAZ). For example, Behnagh et al. [24] reported that the hardness value dropped from $88 \mathrm{HV}$ in BM to $72 \mathrm{HV}$ in friction stir processed AA5083 because of precipitate dissolution. Leal et al. [29] reported that the lowest hardness occurred at the HAZ of FSWed Al5083 because of coarse grain occurrence. Therefore, a post welding process is required to improve the mechanical properties of FSWed AA5083. Post-weld cold rolling (PWCR) may have the most significant potential as a low heat input process to induce the strain hardening effect on non-heat-treated $\mathrm{Al}$ alloys, which is the main mechanism to strengthen this alloy. Gabrielli et al. [30] studied the effect of the PWCR process on FSWed AA5754. They reported that the CR process less than $10 \%$ in the thickness reduction of FSWed joint can improve the ultimate tensile strength of FSWed joints from $224 \mathrm{MPa}$ to $243 \mathrm{MPa}$.

Furthermore, thickness reduction in butt joints is a limitation in FSW process because of the tool shoulder's forging effect [31]. As a result, the mechanical properties and formability of the FSWed blanks are reduced, and this condition deteriorates with a decrease in the thickness of the sheet. This decrease in thickness worsens the aesthetic appearance of the welded blank assembly. This condition reduces the applicability of FSW. Therefore, cold rolling can be applied as a post-weld technique to have a uniform sheet thickness after the welding process. The cold-rolling increases the strain hardening coefficient and enhances the mechanical strength and formability of the material while maintaining a uniform sheet thickness [32].

To date, research and information about the influence of cold rolling after the FSW of AA5083 are lacking. Therefore, the effect of the cold-rolling strain hardening process on the mechanical properties and deformability of the FSWed samples must be thoroughly investigated. Therefore, this study aimed to investigate the effect of the post-weld cold-rolling (PWCR) process on the microstructure, mechanical properties, and serration-flow behaviour of the stress-strain curves of FSWed samples at a different rolling percentages.

\section{Materials and Methods}

AA5083 sheets were used as the BM in this study. Table 1 shows the chemical composition of the AA5083 sheets. The sheets were cut and machined to approximately $150 \mathrm{~mm} \times 100 \mathrm{~mm} \times 5 \mathrm{~mm}$. For the FSW process, the specimens were fixed and clamped in a butt joint configuration, and a $4.7 \mathrm{~mm}$ long H13 tool pin was used for the joining process, as shown in Figure 1. The pin and shoulder diameters were 5 and $20 \mathrm{~mm}$, respectively. Figure $1 \mathrm{~b}$ shows that the pin tool was set at a three-degree 
tilted angle to the tool axis during the FSW process. After several preliminary tests, the travel and rotational speeds were set at $100 \mathrm{~mm} / \mathrm{min}$ and $1000 \mathrm{rpm}$, respectively.

Table 1. Chemical composition of AA5083-base metal (BM) (wt $\%)$.

\begin{tabular}{cccccc}
\hline Al & Mg & Mn & Cr & Si & Fe \\
\hline Balance & 4.46 & 1.0 & 0.14 & 0.25 & 0.45 \\
\hline
\end{tabular}

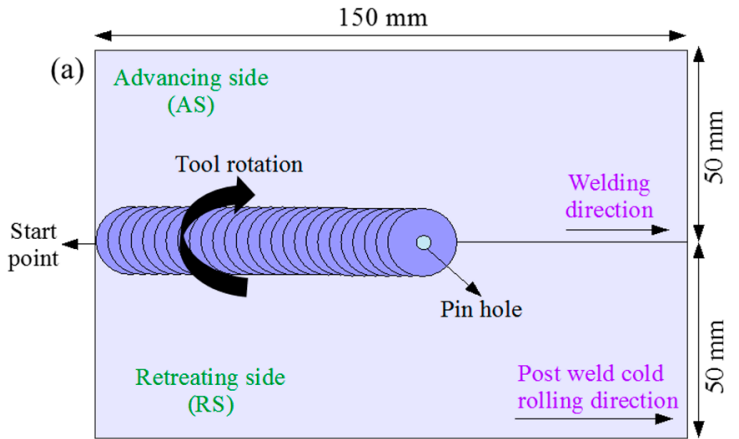

(b)

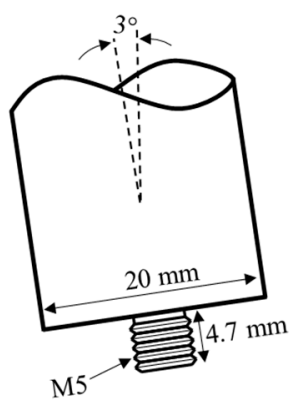

(c)
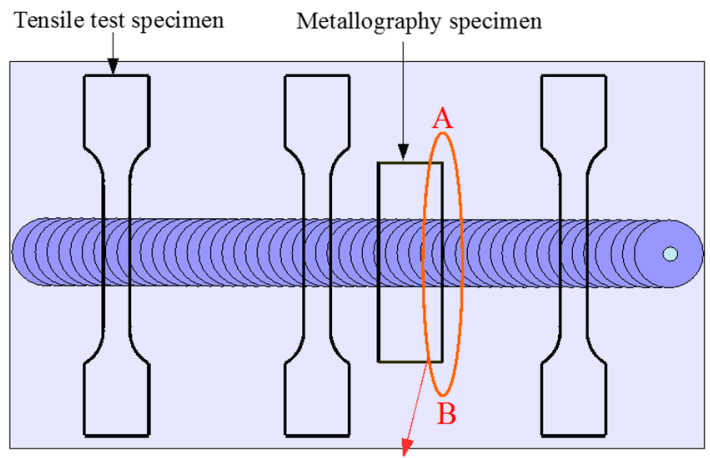

Cross-sectional view

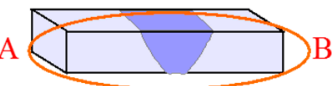

Figure 1. Schematic diagram of the friction stir welding process: (a) butt joint configuration, (b) tilt angle of the welding tool, and (c) location of the machined specimens.

The welded specimens were then subjected to cold-rolling parallel to the welding direction. The cold-rolling reduction percentage was set at $10 \%, 20 \%$, and $40 \%$ from the original thickness of the AA5083 sheets. For simplicity, post-weld cold-rolled (PWCRed)-10\%, PWCRed-20\%, and PWCRed-30\% were used to name the FSWed specimens at different reduction percentages, that is, $10 \%, 20 \%$, and $40 \%$, respectively.

Microstructures were examined at the cross-section of the joint perpendicular to the welding direction. Prior to microstructure observation, the FSWed specimens were cold-mounted and manually ground using sand papers ranging from \#600 to \#2000. The specimens were then polished, which involved the use of a diamond polishing suspension with a particle size of $1 \mu \mathrm{m}$. The microstructure of the AA5083 was revealed by electrochemical etching using Barker's reagent $\left(5 \mathrm{~mL}\right.$ of $\mathrm{HBF}_{4}$ and $100 \mathrm{~mL}$ of $\mathrm{H}_{2} \mathrm{O}$ ) at $20 \mathrm{VDC}$. Weld zone microstructures were analysed via optical microscopy. The measurement of the average grain size was in accordance with the ASTM Standard E112-10. X-Ray Diffraction (XRD) analysis was carried out to distinguish the dislocation density of the samples via a Bruker AXS Germany diffractometer with a monochromatic $\mathrm{Cu}-\mathrm{K} \alpha$ radiation of $\lambda=0.1541 \mathrm{~nm}$ at $40 \mathrm{kV}$ and $4 \mathrm{~mA}$. The $100 \mathrm{kN}$ Zwick universal testing machine with a crosshead speed of $1.8 \mathrm{~mm} / \mathrm{min}$ was employed for tensile tests at room temperature. The three tensiles were tested for each condition. The specimens were machined normal to welding direction with the gauge length of $40 \mathrm{~mm}$ and a width of $6 \mathrm{~mm}$. This condition complies with the ASTM Standard E8M-04. Zwick Vickers hardness 
machine was employed to evaluate micro-hardness along the cross-section of the FSWed samples using a load of $0.1 \mathrm{kgf}$ and dwell time of $15 \mathrm{~s}$. The fractography of the samples was performed after tensile test to study the fracture mode of samples via the ZEISS MERLIN field emission scanning electron microscope (FE-SEM) (Jena, Thuringia, Germany).

\section{Results and Discussion}

\subsection{Microstructure}

A cross section of the FSWed and PWCRed samples was observed to investigate microstructure and welding defects after welding and rolling. The as-weld sample showed no internal defects at the cross sections of the welding joints, as shown in Figure 2. The SZ was basin-shaped, as shown in Figure 2a. This shape has been reported for the first time by Sato et al. [33]. A clear borderline that indicates the nugget zone (NZ) and thermomechanically affected zone (TMAZ) at AS was located below the shoulder area.

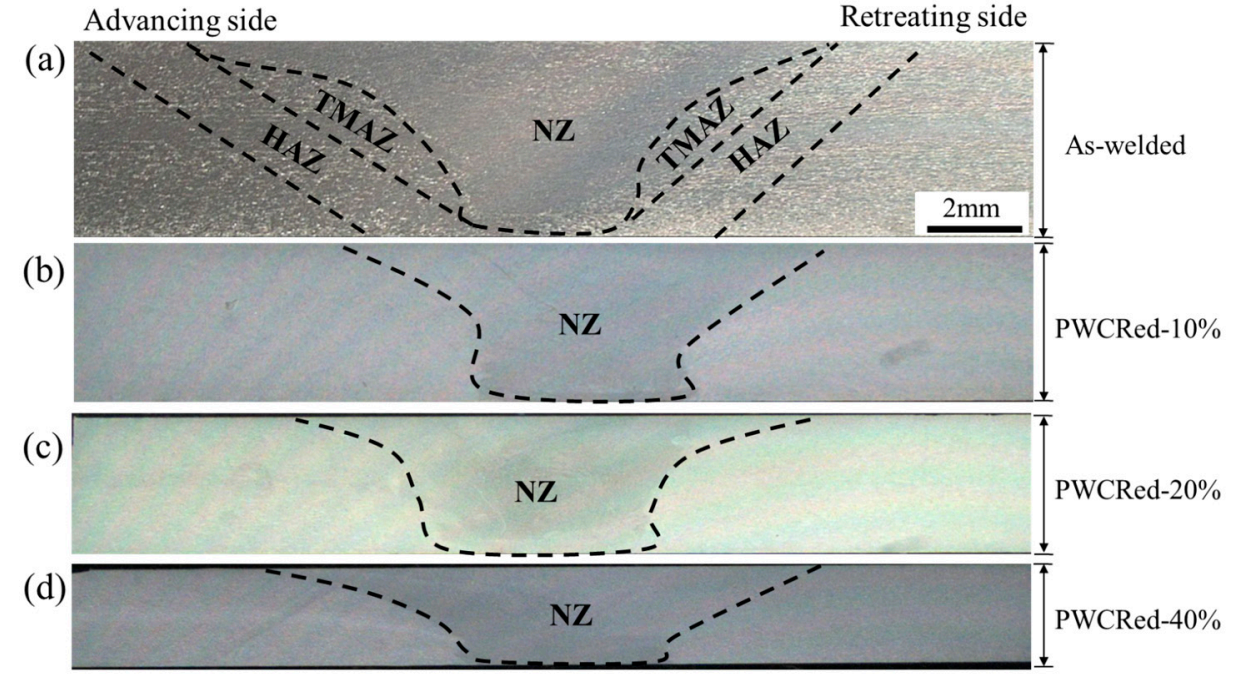

Figure 2. Cross-sectional view; (a) as-weld sample, (b) post-weld cold-rolling (PWCR)ed-10\%, (c) PWCRed-20\%, and (d) PWCRed-40\%.

Figure $2 \mathrm{~b}-\mathrm{d}$ show the cross-section of PWCRed-10\%, PWCRed-20\%, and PWCRed-40\%, respectively. Increasing the rolling percentage has compressed the thickness of the welding plate. The weld zone became wider by increasing of CR percentages compared with the welding zone of the as-welded sample without any cracks at the middle of cold-rolled samples. The NZ area of PWCRed $-40 \%$ was the widest compared with other samples because of the highest strain imposed on the sample. Furthermore, Figure 3 shows the microstructures of the as-weld and PWCRed samples in advancing and retreating sides. As shown in Figure 3, the borderline between NZ and TMAZ was observed at AS, in contrast with RS. The matter on RS is much less transported around the tool before being deposited in the welding line when compared with the matter on AS $[34,35]$. 

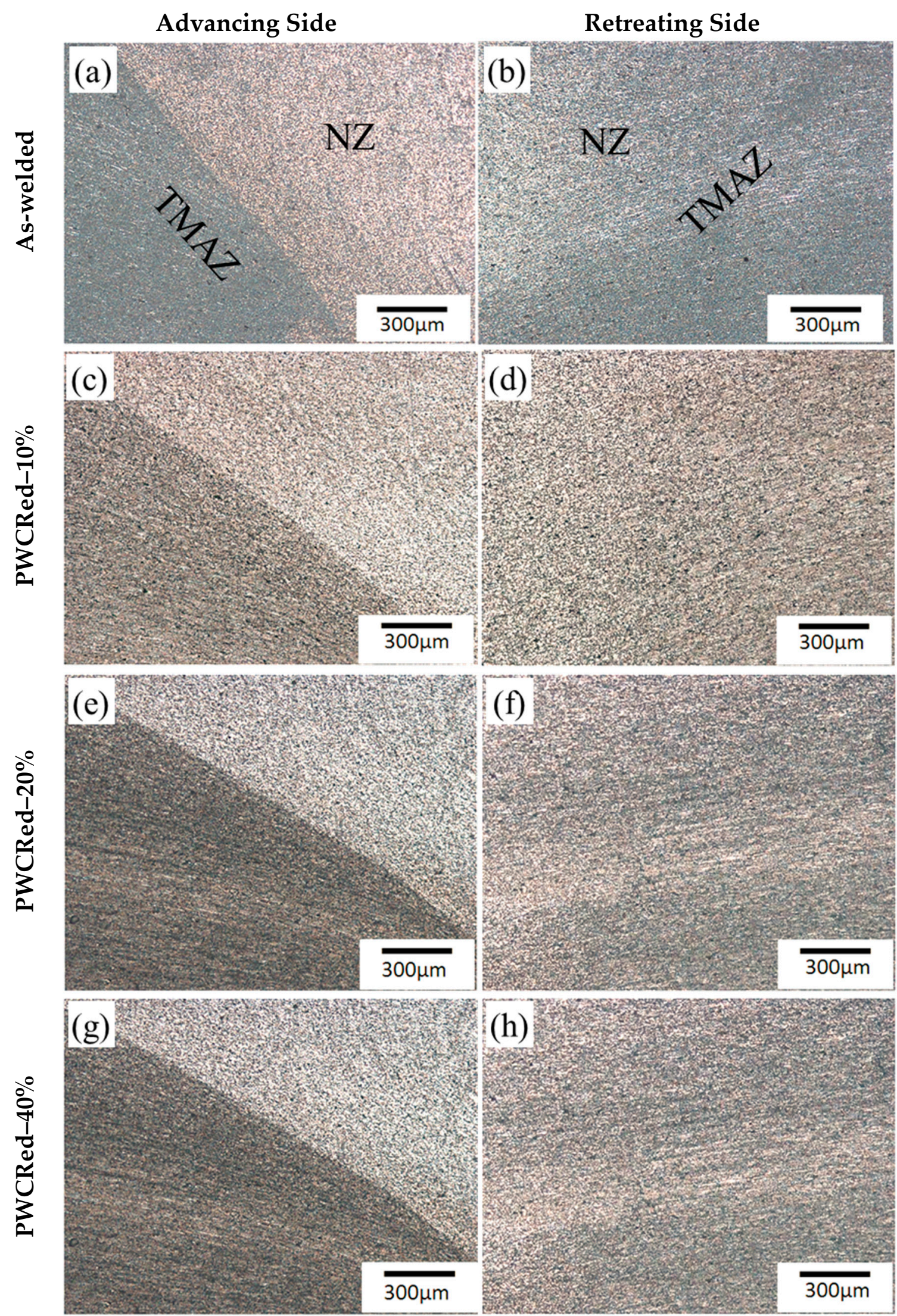

Figure 3. Microstructures of the as-welded and post-weld cold-rolled samples.

TMAZ, thermomechanically affected zone; NZ, nugget zone. 
Figure 4a shows the typical Al structure of as-received AA5083 with the average grain size of 21 $\mu \mathrm{m}$. Dynamic recrystallisation and equiaxed grain microstructure with an average grain size of 14 $\mu \mathrm{m}$ were observed in the NZ of the as-welded sample because of the mechanical strain and frictional heat of the rotating tool, as presented in Figure $4 \mathrm{~b}$. As shown in Figure $4 c-h$, rolling was performed to compress and elongate the microstructure parallel to the rolling direction in weld zones of the rolled samples. The rolling process decreased the average grain size of FSWed samples, especially in SZ, in which they recrystallised and formed very fine microstructures. The average grain size of BMs was 19, 16, and $9 \mu \mathrm{m}$ for PWCRed-10\%, PWCRed-20\%, and PWCRed-40\%, respectively, as presented in Figure $4 c, e, g$.
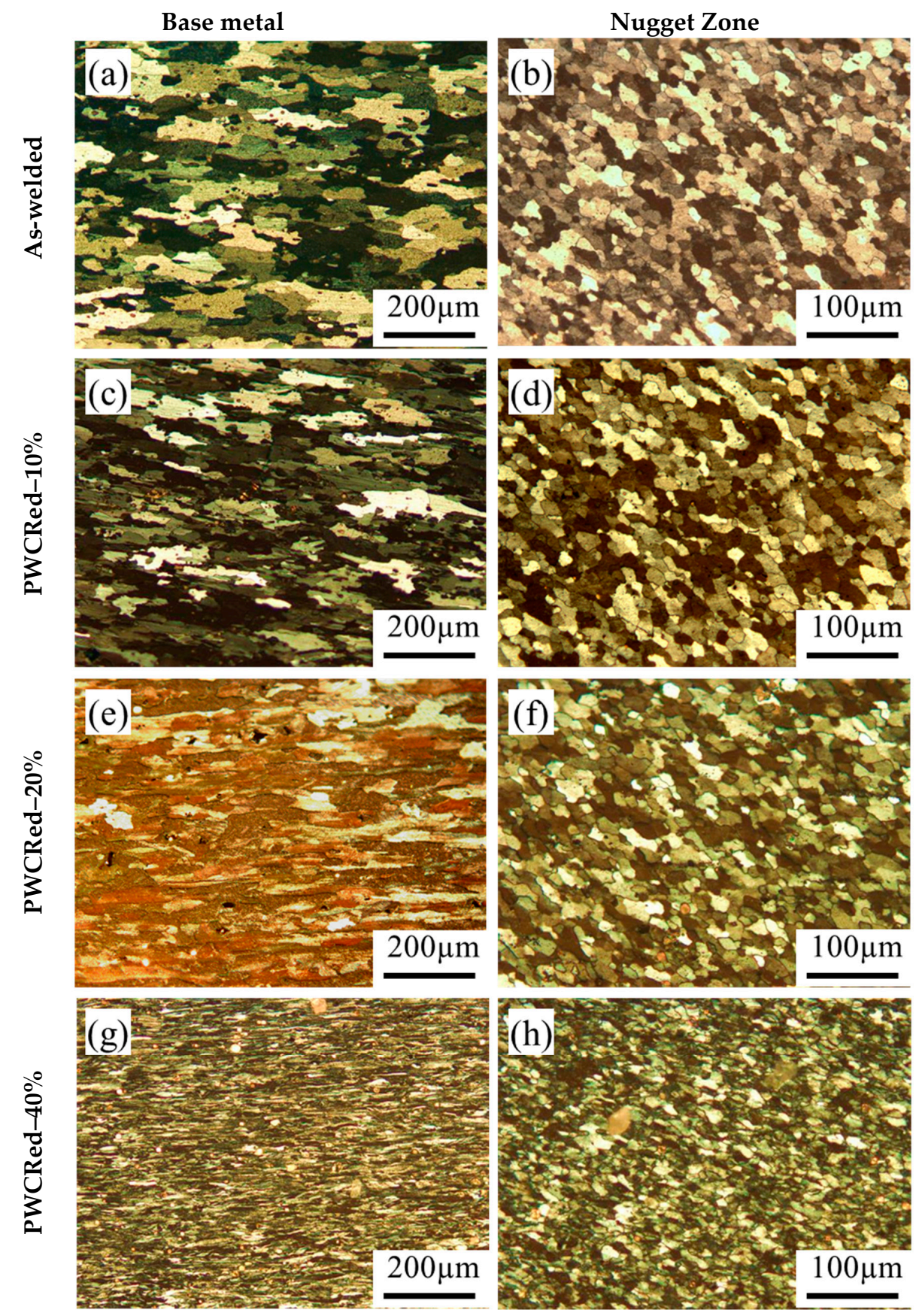

Figure 4. Microstructures of the base metal and nugget zone before and after the post-weld cold-rolled process. (a,b) as-welded, (c,d) PWCRed-10\%, (e,f) PWCRed-20\%, (g,h) PWCRed-40\%. 
The average grain size in the NZ also decreased because of the increase in the percentage of rolling, whereas the NZ grain sizes of PWCRed-10\%, PWCRed-20\%, and PWCRed-40\% were 13, 9, and $6 \mu \mathrm{m}$, respectively. The plastic deformation and, consequently, the average grain size reduction in the welding zone could increase the dislocation density and improve the mechanical strength of materials $[36,37]$. The alteration of dislocation density after PWCR will be discussed further.

\subsection{Tensile Properties}

The tensile properties and stress-strain curves of AA5083-BM, as-welded, and PWCRed samples are shown in Table 2 and Figure 5, respectively. FSW reduced the tensile strength of the AA5083-BM, whereas rolling improved the mechanical properties of the welded samples. The tensile strength of the BM decreased to $262 \mathrm{MPa}$ after FSW because of frictional heat induced by the softening behaviour and increased grain size [38].

Table 2. Tensile properties of AA5083-BM, as-welded, and post-weld cold-rolling (PWCR)ed samples.

\begin{tabular}{cccc}
\hline Sample & Tensile Strength (MPa) & Elongation (\%) & Welding Efficiency (\%) \\
\hline AA5083-BM & 328 & 22 & - \\
As-welded & 262 & 7.3 & 80 \\
PWCRed-10\% & 321 & 8.6 & 98 \\
PWCRed-20\% & 350 & 8.4 & 107 \\
PWCRed-40\% & 403 & 7.9 & 123 \\
\hline
\end{tabular}

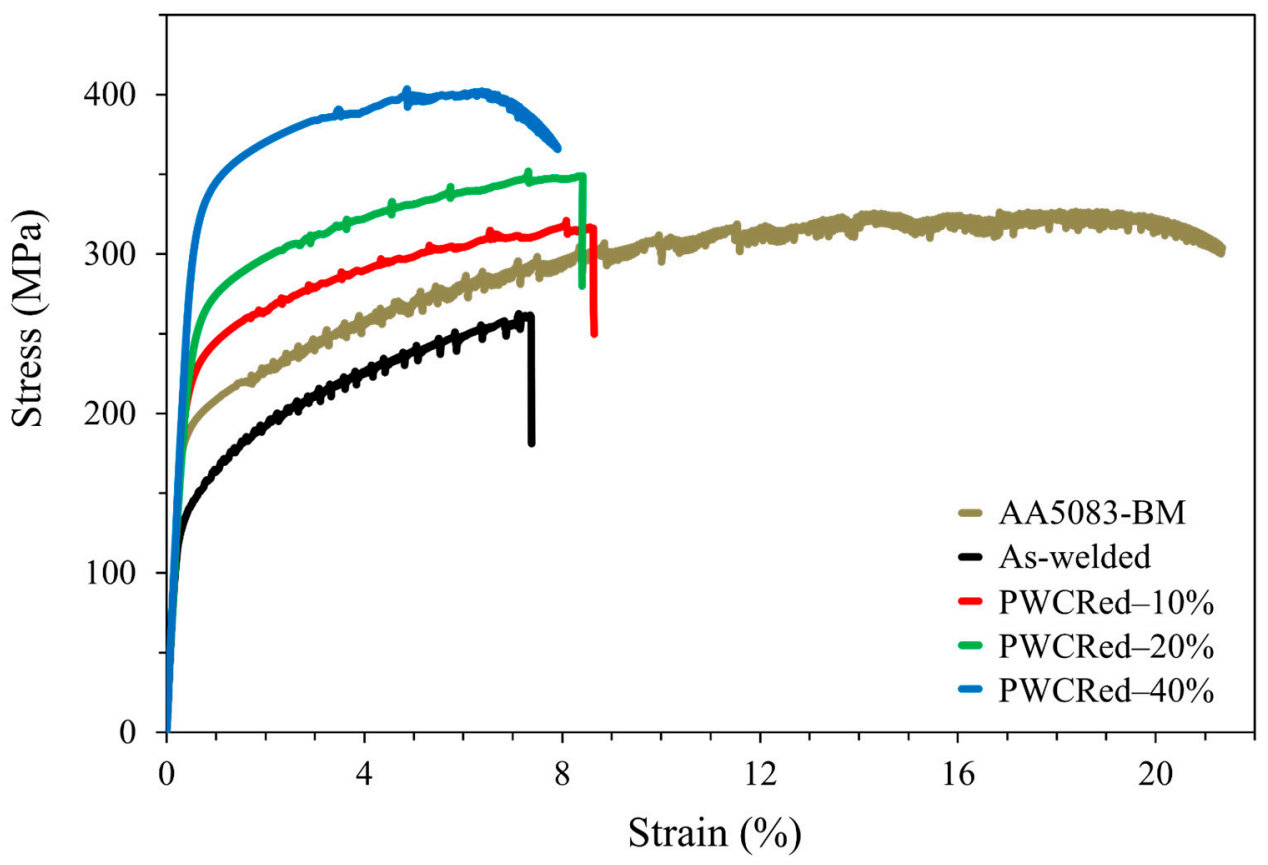

Figure 5. Stress-strain diagram of the AA5083-base metal (BM), as-welded, and PWCRed samples.

The cold-rolled strain hardening increased the yield and ultimate strength of joints as a result of the decreasing average grain size based on the Hall-Petch equation [39]. Furthermore, the elongation of the rolled samples (approximately 8\%) was not significantly different compared with that of the as-weld sample. The tensile strength was increased to 321, 350, and $403 \mathrm{MPa}$ by PWCRed-10\%, PWCRed-20\%, and PWCRed-40\%, respectively. Correspondingly, the elongation of the rolled samples slightly decreased by increasing of reduction percentage as a result of average grain size reduction. Grain refinement is well known as a method that can increase the strength of metallic materials without decreasing their ductility. Moreover, welding efficiency increased from $98 \%$ to $123 \%$ by increasing the 
rolling percentages from $10 \%$ to $40 \%$. Welding efficiency is the ratio of the tensile strength of PWCRed sample and the BM.

The serration-flow behaviour effect observed in the stress-strain diagrams of the as-welded and PWCRed samples is typical behaviour of Al-Mg alloys [28] that is directly attributed to the dislocation density in the structure of the sample, as presented in Figure 6. The dislocation movement in the AA5083 is hindered by the Mg atom in substitutional solid solution of Al-Mg alloy [40]. Furthermore, it influences the properties of AA5083 by the creation of serration-flow behaviour in the stress-strain curve during the tensile loading [41]. This serration-flow behaviour is called the Portevin-Le Chatelier (PLC) effect during the plastic deformation of the material [28]. The substitute and interstitial alloys, such as Al alloys [42], carbon steel [43], and copper alloys [44], tend to demonstrate PLC behaviour during tensile loading [45]. The PLC effect is related to pinning and unpinning processes, where the pinned process has occurred when the dislocation is stuck by obstacles formed from the forest dislocations and grain boundaries. Otherwise, the unpinned process occurs when the dislocation can be overcome from the solute cloud, leading to a stress drop during the tensile curve [46]. The problems caused by PLC are the decreasing of formability of materials and the formation of undesired band mark on the specimen surface [47].
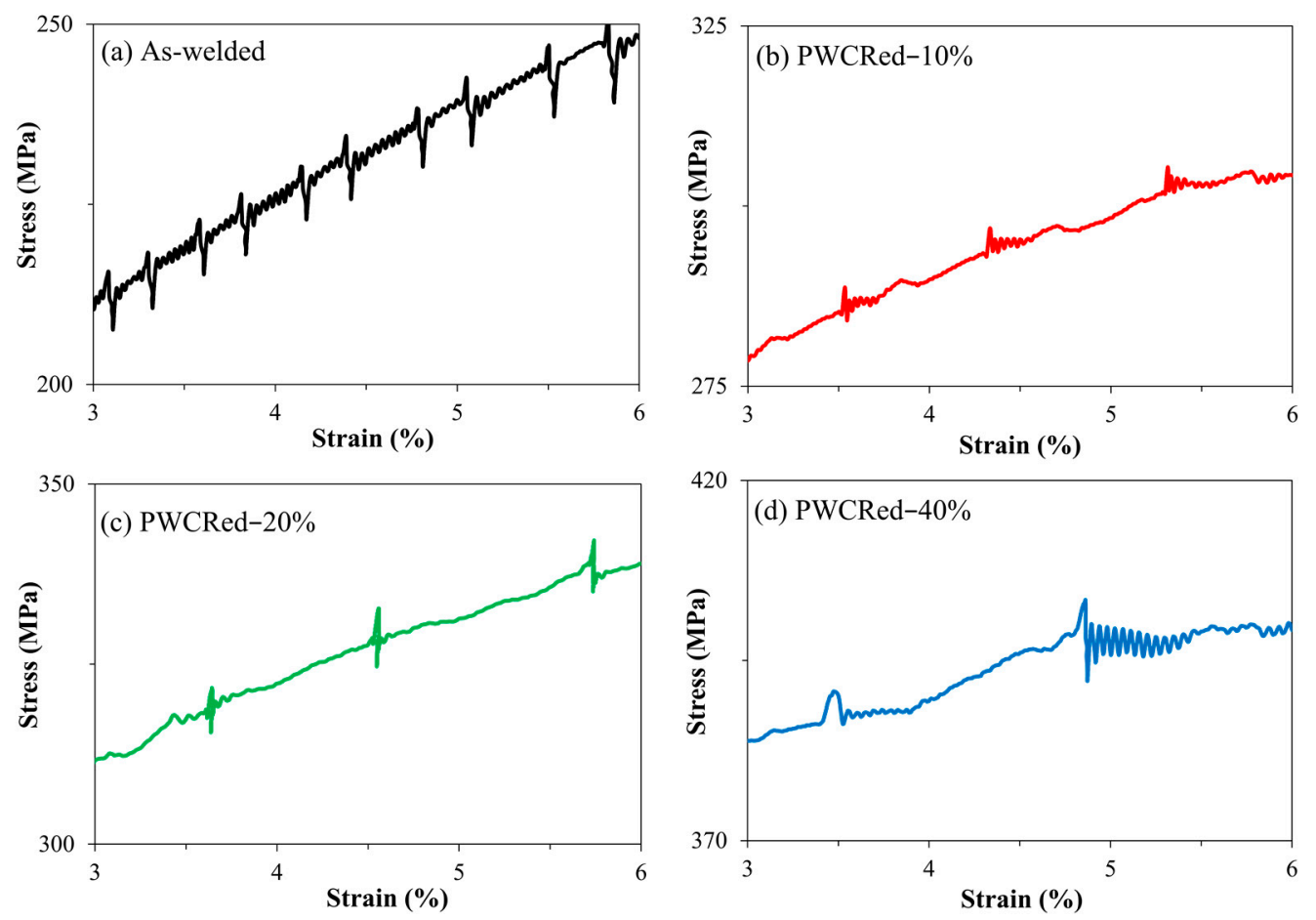

Figure 6. Portevin-Le Chatelier (PLC) behaviour of the as-welded and PWCRed samples.

Furthermore, the stress-strain curves of PWCRed specimens showed different serration-flow frequencies under a different rolling percentage, as shown in Figure 6. Increasing the cold-rolling percentage results in an increase in dislocation that piles up at the grain boundaries, as well as an increase in the strain hardening, leading to the higher tensile strength values [48]. Furthermore, the finer grains result in denser and uniform dislocation structure at higher deformation levels. In addition, the changes of wrinkle behaviour in the PWCRed- $40 \%$ sample are consistent with the ideas of a homogeneously uniform distribution of the dislocations. The uniform plastic flow is suggested to occur in those subjected to a regular form and finer grain of $\mathrm{Al} \mathrm{[49-51].}$

Cold working leads to two remarkable changes in the microstructure of materials, namely, grain size and dislocation density, which in turn affect the performance enhancement of the materials. In general, materials with smaller grain size have higher mechanical properties than those with bigger 
grain size under the same cold-rolling conditions. This results because of the increase in dislocation density associated with high reduction rolling effect, leading to high plastic deformation and grain size reduction. Therefore, the influence of the dislocation density in FSWed and PWCRed samples must be considered. Figure 7 shows the XRD patterns of the as-welded and PWCRed samples.

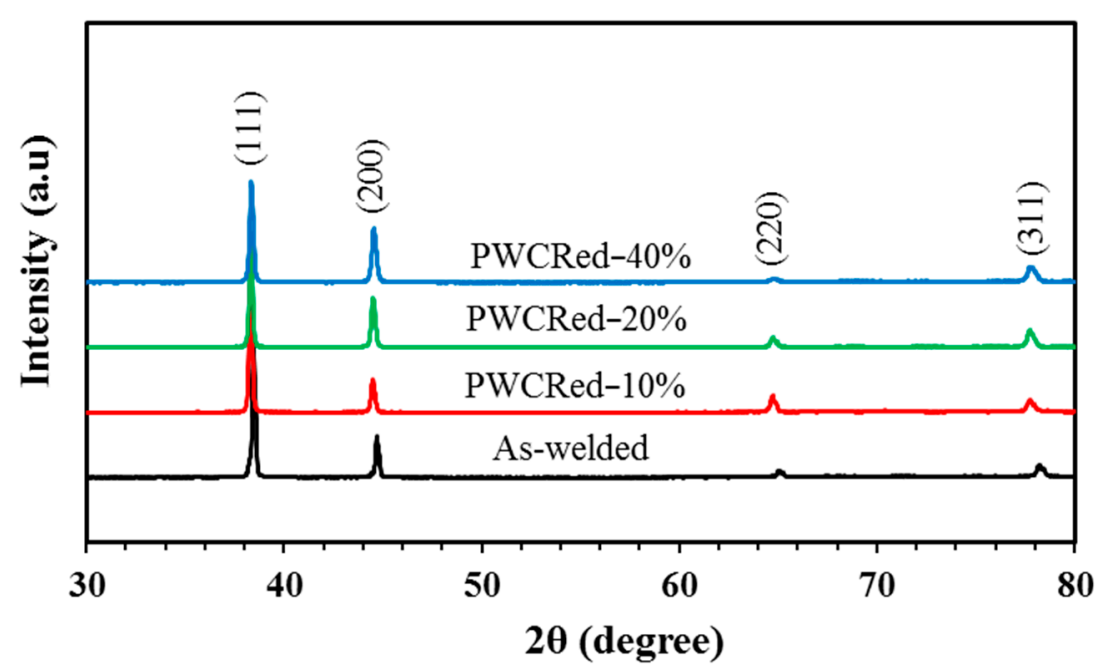

Figure 7. XRD patterns of the as-welded and PWCRed samples.

The value of the dislocation density $\rho\left(\mathrm{m}^{-2}\right)$ can be obtained from the average values of the crystallite size $(d)$ and microstrain $\left\langle\eta^{2}\right\rangle^{1 / 2}$ using the following equation [52,53]:

$$
\rho=\frac{2 \sqrt{3}\left\langle\eta^{2}\right\rangle^{\frac{1}{2}}}{d \times b}
$$

where $d$ and $\eta$ are calculated from the Williamson-Hall method, and Burgers vector $(b)$ is calculated via $b=\frac{a}{\sqrt{2}}$ [54] (a is the lattice parameters of the as-welded and cold-rolled samples obtained from the Nelson-Riley method). Using Equation (2), the average crystallite size and microstrain can be calculated from the y-intercept and slope of the curves, respectively, which are obtained from the linear fitting of the Williamson-Hall plot, as shown in Figure 8:

$$
F W H M \times \cos (\theta)=\frac{0.9 \lambda}{d}+2 \eta \sin (\theta),
$$

where $F W H M$ is the full width at the half-maximum intensity of the selected peak, $\theta$ is the Bragg's diffraction angle, and $\lambda$ is $0.1541 \mathrm{~nm}$ for the wavelength of $\mathrm{Cu}-\mathrm{K} \alpha$ radiation. Figure 8 is described further in Table 3, which indicates a decrease in the samples' crystallite size and an increase in strain with increased cold-rolling percentage. At $40 \%$ reduction, the crystallite size was decreased to a minimum value of $69.35 \mathrm{~nm}$, whereas the lattice strain increased to a maximum value of 0.30 . These findings demonstrate that the thickness reduction by cold-rolling could change the crystallite size $(d)$ and strain $(\eta)$. 


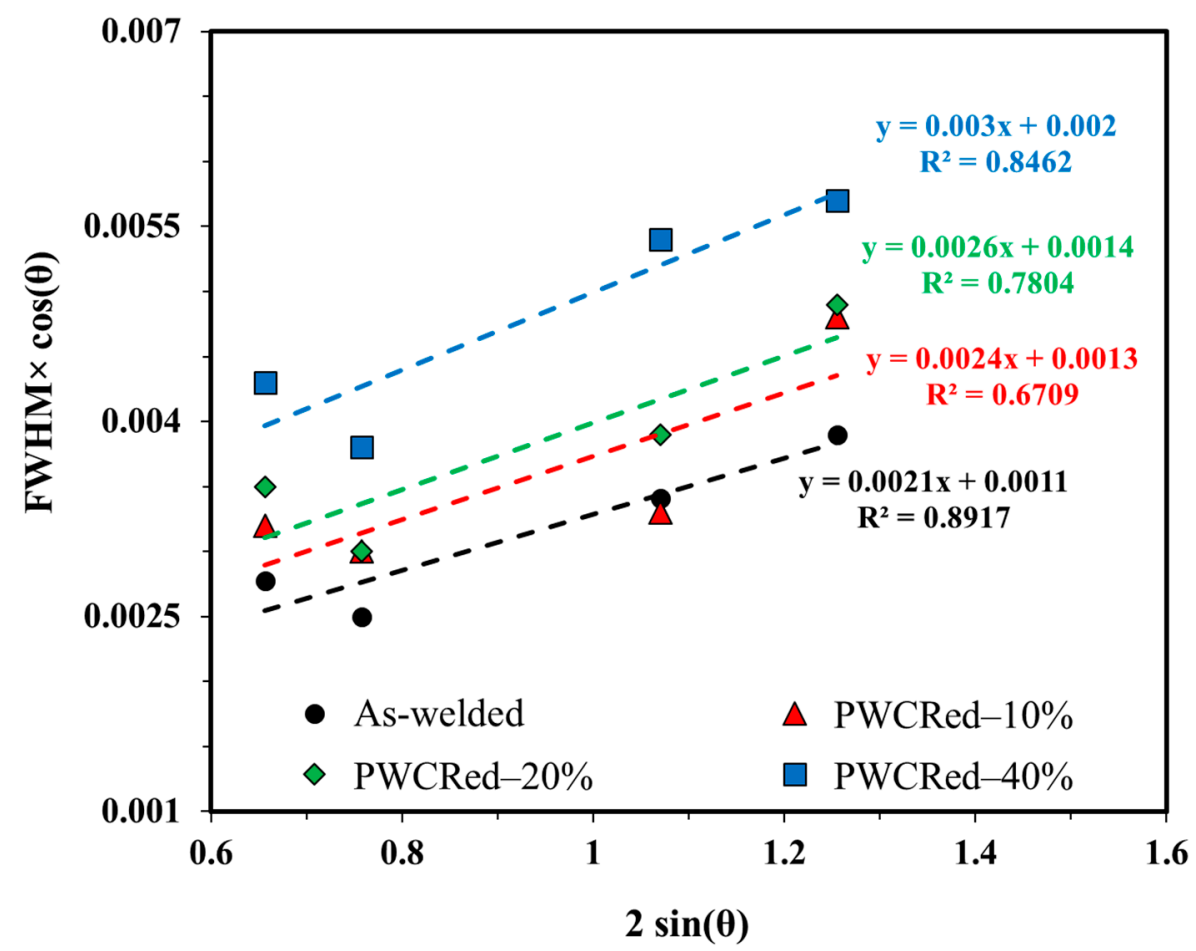

Figure 8. Obtaining crystallite size and strain rolled samples after different reduction based on the Williamson-Hall method. FWHM, full width at the half-maximum intensity.

Table 3. Mean crystallite size and strain amount of the rolled sample based on the Williamson-Hall equation.

\begin{tabular}{ccccc}
\hline \multirow{2}{*}{ Sample } & \multicolumn{2}{c}{$\mathrm{Y}=\boldsymbol{\alpha X + \beta}$} & $\boldsymbol{d}$ (n.m) & $\eta(\mathbf{\%})$ \\
\cline { 2 - 3 } & $\boldsymbol{\alpha}$ & $\boldsymbol{\beta}$ & & \\
\hline As-welded & 0.0021 & 0.0011 & 126.08 & 0.21 \\
PWCRed-10\% & 0.0024 & 0.0013 & 106.68 & 0.24 \\
PWCRed-20\% & 0.0026 & 0.0014 & 99.06 & 0.26 \\
PWCRed-40\% & 0.0030 & 0.0020 & 69.35 & 0.30 \\
\hline
\end{tabular}

Notably, the Burgers vector $(B)$ can be changed during rolling because of microstrain-induced disturbances, which are caused by the lattice parameter of Al deviating from the database of FCC $(a=0.4094 \mathrm{~nm}[55])$. The Nelson-Riley function (Equation (3)) was utilised to obtain the lattice parameter of $\mathrm{Al}$, as follows [53,56]:

$$
F(\theta)=\frac{1}{2}\left(\frac{\cos ^{2} \theta}{\sin \theta}+\frac{\cos ^{2} \theta}{\theta}\right),
$$

where $F(\theta)$ is the Nelson-Riley function and $\theta$ is the Bragg's diffraction angle. The lattice parameter of $\mathrm{Al}$ as a function of $F(\theta)$ is shown in Figure 9. The values of lattice parameter, Burgers vector, and dislocation density of the as-welded and PWCRed samples are summarised in Table 4. 


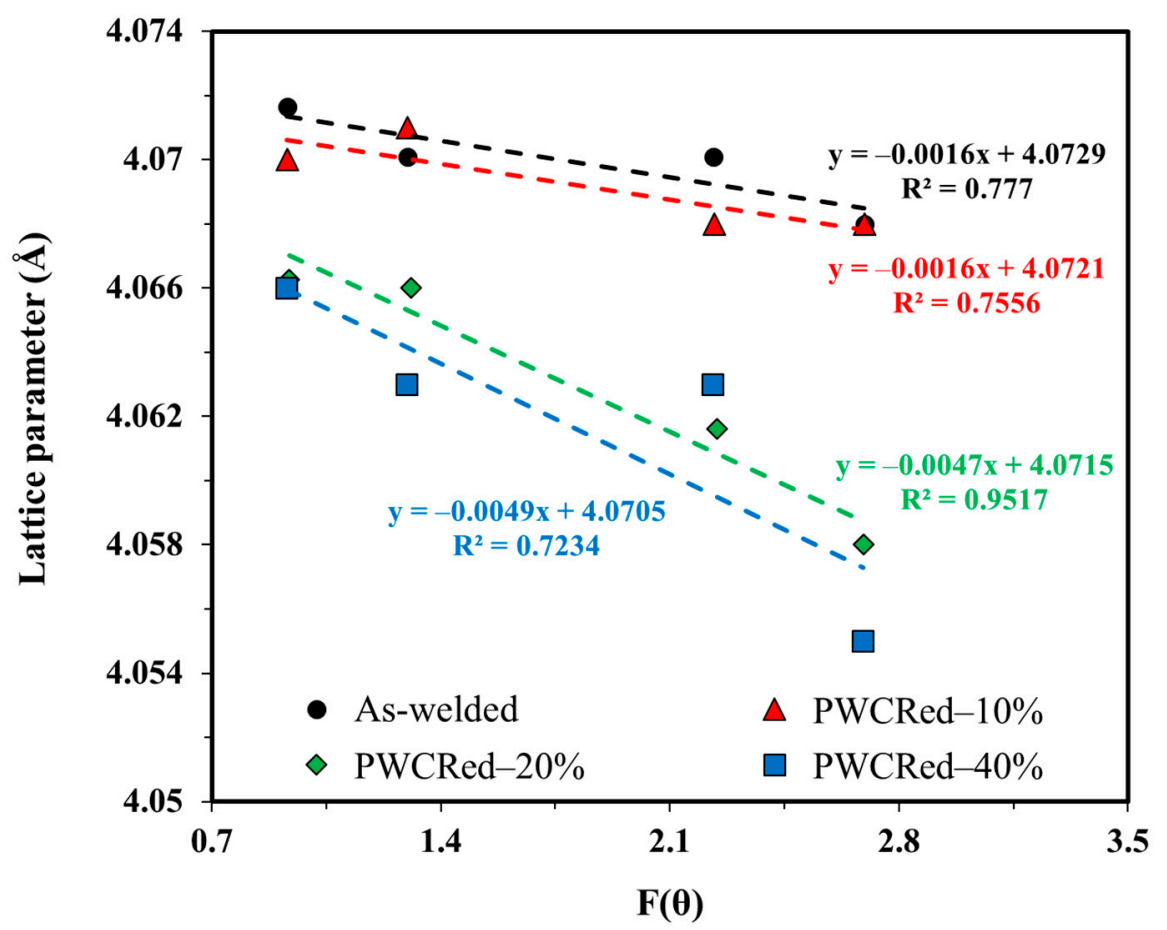

Figure 9. Obtaining lattice parameters of post-weld cold-rolled samples after different reduction based on the Nelson-Riley function.

Table 4. The values of lattice parameter, Burgers vector, and dislocation density of the as-welded and PWCRed samples.

\begin{tabular}{cccc}
\hline Sample & $\begin{array}{c}\boldsymbol{a} \text { (Nelson-Riley } \\
\text { Method) }(\AA)\end{array}$ & $\boldsymbol{b} \mathbf{( \mathbf { 1 0 }}-\mathbf{1 0} \mathbf{~ m})$ & $\boldsymbol{\rho} \times \mathbf{1 0}^{\mathbf{1 4}}\left(\mathbf{m}^{\mathbf{- 2}}\right)$ \\
\hline As-welded & 4.0729 & 2.87998 & 2.00340 \\
PWCRed-10\% & 4.0721 & 2.87941 & 2.70643 \\
PWCRed-20\% & 4.0715 & 2.87899 & 3.15797 \\
PWCRed-40\% & 4.0705 & 2.87828 & 5.20672 \\
\hline
\end{tabular}

As presented in Table 4, the values of lattice parameter and Burgers vector are not significantly different. However, the dislocation density increased with the increasing of rolling percentages. The dislocation density increased significantly at $40 \%$ rolling percentage. This phenomenon is believed to be attributed to the intrinsic capacity of dislocations that interact with one another during rolling by creating stress fields within the material. The interaction between the stress fields of dislocations can act as an obstacle against dislocation motion by attractive or repulsive interactions. At this time, the mechanical properties of the materials can be improved owing to the disrupted motion of dislocations. The frequencies of serration are different because of the stress fields of the grain size, in which the serration frequency is high for the as-welded sample. After rolling, the serration causes the stress to increase with increased rolling percentage because of the pinning effect [42]. Thus, the strain hardening increasing during rolling results in decreasing crystallite size and lattice strain for the sample.

\subsection{Fractography}

The fracture surface of the as-welded and cold rolled samples was examined after the tensile test. Figure 10 shows the fracture surfaces of as-welded, PWCRed-10\%, and PWCRed-40\% samples. The fracture occurred from the boundary between NZ and TMAZ in the as-welded sample to HAZ in PWCRed-10\% and PWCRed-40\%. 


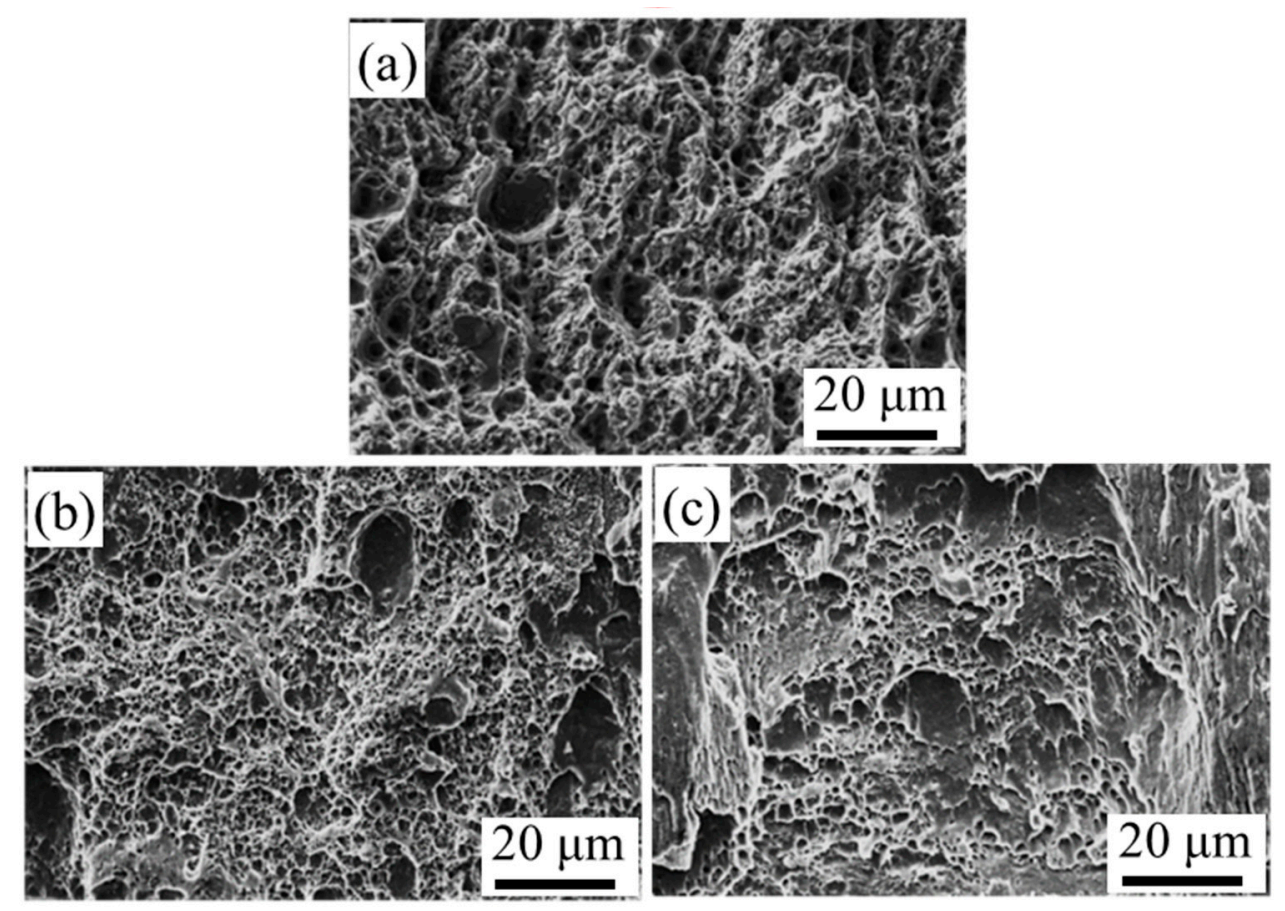

Figure 10. Scanning electron microscope (SEM) observation of tensile fracture surface: (a) as-welded, (b) PWCR-10\%, and (c) PWCR-40\% samples.

SEM observation showed dimple fracture of the as-welded sample (Figure 10a) compared with the PWCRed samples. This result indicates a ductile fracture behaviour of the as-welded joint showing the lowest tensile strength in the as-welded condition (Figure 5). The various sizes of dimples with shear effect were observed on the fracture surfaces of PWCRed-10\% and PWCRed-40\% samples. Dimple size decreased with increased rolling from $10 \%$ to $40 \%$, as presented in Figure $10 \mathrm{~b}$ and c. Imperfect feature, as well as the small size of dimples, has been an indication for the brittleness with low ductility of joints [57]. Shallow dimples and flat surfaces were obtained at PWCRed-10\%, and PWCRed-40\% can be related to brittle fracture behaviour compared with the as-welded sample after the tensile test. This result provides evidence of the increased tensile strength in PWCRed samples.

\subsection{Vickers Hardness}

Evolution of the hardness values along the welded joints of the specimens was measured using the Vickers micro-hardness tester. The hardness profiles measured starting from the base metal of the advancing side to the retreating side are shown in Figure 11. The values of hardness are closely related to the microstructural evolutions that occurred within the weldments at each process, that is, FSW, cold-rolling processes. Hardness profiles are different depending on the welding regions and cold-rolling percentage. The initial hardness of AW55 was $90 \pm 2 \mathrm{HV}$. The hardness of weldments then started to decrease when approaching the HAZ. Minimum hardness was attained at the TMAZ (i.e., 82-85 HV). Cold rolling improved the hardness of the welded joint, and the hardness increased from $93 \pm 2 \mathrm{HV}$ to $106 \pm 2 \mathrm{HV}$ when the thickness-reduction percentage was increased from $10 \%$ to $40 \%$. This phenomenon is attributable to the decreasing grain sizes that led to the improved hardness of the materials in association with the Hall-Petch equation [58]. Furthermore, good agreement was found between hardness profile results, tensile strength, and the fracture location of the samples after the tensile test. Thus, the fracture occurred in the region of low hardness values, that is, HAZ and TMAZ. 


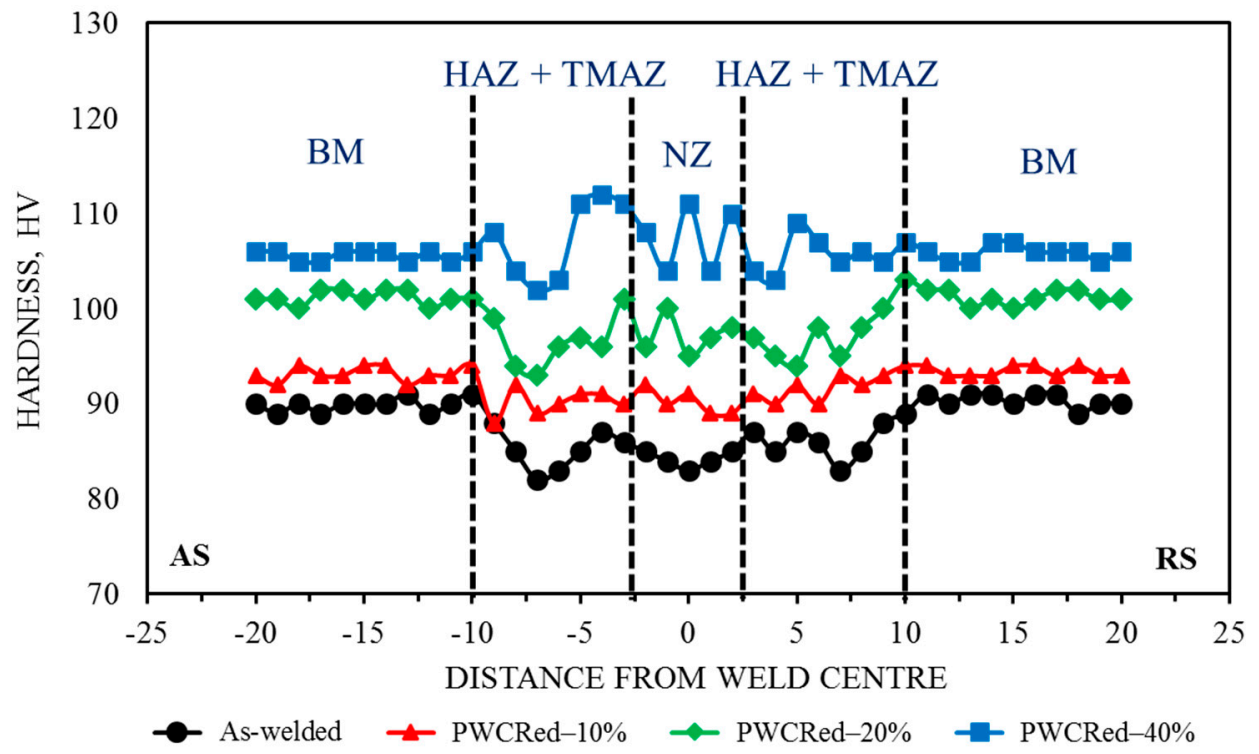

Figure 11. Hardness profile of the as-welded and PWCRed samples. HAZ, heat affected zone; TMAZ, thermomechanically affected zone; BM, base metal.

\section{Conclusions}

FSW was performed to join a similar AA5083 Al alloy and the welded specimens obtained without any defects. The FSWed specimens were then subjected to the PWCR process. The mechanical properties of the PWCRed specimens were improved owing to the induced strain hardening. PWCRed samples without any defects were successfully produced at different thickness reductions of $10 \%$, $20 \%$, and $40 \%$. The average grain size in NZ and BM reduced more with the increase of cold-rolling percentage because of the increase in plastic deformation imposed on the samples. The average grain size of SZ in the as-welded sample decreased from $14 \mu \mathrm{m}$ to a smaller grain size of 13,9 , and $6 \mu \mathrm{m}$ by cold-rolling at $10 \%, 20 \%$, and $40 \%$ thickness reduction, respectively. Furthermore, PLC behaviour was observed in the stress-strain curve of as-welded and PWCRed samples such that the serration-flow frequency decreased with increased thickness reduction because of the strain hardening induced during rolling and dislocation motion. The tensile strength of the BM was reduced by approximately $20 \%$ after FSW. However, the PWCR process reduced the serration effect in tensile behaviour and improved the tensile strength of the joint samples. The tensile strength increased to $403 \mathrm{MPa}$ at $40 \%$ of PWCR and demonstrated a $123 \%$ improvement in welding efficiency owing to the disrupted motion of dislocations and increasing dislocation density from $2.00340 \times 1014 \mathrm{~m}^{-2}$ in the as-welded sample up to $5.20672 \times 1014 \mathrm{~m}^{-2}$ in the PWCRed-40\% sample.

Author Contributions: Conceptualization, Z.S. and N.F.M.S.; methodology, N.F.M.S. and A.H.B.; formal analysis, N.F.M.S., A.H.B., and A.R.; investigation, Z.S., N.F.M.S., and A.H.B.; writing-original draft preparation, N.F.M.S.; writing-review and editing, Z.S., A.H.B., J.S., and A.R.; visualization, Z.S. and A.H.B.; supervision, Z.S., A.H.K., J.S., and M.Z.O.; project administration, Z.S., A.H.K., J.S., and M.Z.O. All authors have read and agreed to the published version of the manuscript.

Funding: This research was funded by The Ministry of Higher Education, Malaysia (MOHE), grant number FRGS/1/2013/TK01/UKM/02/4.

Conflicts of Interest: The authors declare no conflict of interest.

\section{References}

1. Missori, S.; Sili, A. Mechanical behaviour of 6082-T6 aluminium alloy welds. Metall. Sci. Technol. 2000, 18, $12-18$.

2. Poznak, A.; Freiberg, D.; Sanders, P. Automotive Wrought Aluminium Alloys. In Fundamentals of Aluminium Metallurgy; Elsevier: Amsterdam, The Netherlands, 2018; pp. 333-386. 
3. Demir, H.; Gündüz, S. The effects of aging on machinability of 6061 aluminium alloy. Mater. Des. 2009, 30, 1480-1483. [CrossRef]

4. Elangovan, K.; Balasubramanian, V. Influences of post-weld heat treatment on tensile properties of friction stir-welded AA6061 aluminum alloy joints. Mater. Charact. 2008, 59, 1168-1177. [CrossRef]

5. Wang, B.; Xue, S.; Ma, C.; Wang, J.; Lin, Z. Effects of porosity, heat input and post-weld heat treatment on the microstructure and mechanical properties of TIG welded joints of AA6082-T6. Metals 2017, 7, 463. [CrossRef]

6. Deekhunthod, R.N. Weld Quality in Aluminium Alloys. Master's Thesis, University of Uppsala, Uppsala, Sweden, 23 May 2014.

7. Carron, D.; Bastid, P.; Yin, Y.; Faulkner, R.G. Modelling of precipitation during friction stir welding of an Al-Mg-Si alloy. Tech. Mech. 2010, 30, 29-44.

8. Dong, J.; Zhang, D.; Zhang, W.; Zhang, W.; Qiu, C. Microstructure evolution during dissimilar friction stir welding of AA7003-T4 and AA6060-T4. Materials 2018, 11, 342. [CrossRef]

9. Selamat, N.F.M.; Baghdadi, A.H.; Sajuri, Z.; Kokabi, A.H. Friction stir welding of similar and dissimilar aluminium alloys for automotive applications. Int. J. Automot. Mech. Eng. 2016, 13, 3401. [CrossRef]

10. Baghdadi, A.H.; Selamat, N.F.M.; Sajuri, Z. Effect of tool offsetting on microstructure and mechanical properties dissimilar friction stir welded Mg-Al alloys. IOP Conf. Ser. Mater. Sci. Eng. 2017, 238, 12018. [CrossRef]

11. Nakamura, T.; Obikawa, T.; Nishizaki, I.; Enomoto, M.; Fang, Z. Friction stir welding of non-heat-treatable high-strength alloy 5083-O. Metals 2018, 8, 208. [CrossRef]

12. Picot, F.; Gueydan, A.; Martinez, M.; Moisy, F.; Hug, E. A correlation between the ultimate shear stress and the thickness affected by intermetallic compounds in friction stir welding of dissimilar aluminum alloy-stainless steel joints. Metals 2018, 8, 179. [CrossRef]

13. Osman, N.; Sajuri, Z.; Baghdadi, A.H.; Omar, M.Z. Effect of process parameters on interfacial bonding properties of aluminium-copper clad sheet processed by multi-pass friction stir-welding technique. Metals 2019, 9, 1159. [CrossRef]

14. Shah, S.; Tosunoglu, S. Friction stir welding: Current state of the art and future prospects. In Proceedings of the 16th World Multi-Conference on Systemics, Cybernetics and Informatics, Orlando, FA, USA, 17-20 July 2012; pp. 17-20.

15. Sibalic, N.; Vukcevic, M. Numerical Simulation for FSW Process at Welding Aluminium Alloy AA6082-T6. Metals 2019, 9, 747. [CrossRef]

16. Amini, A.; Asadi, P.; Zolghadr, P. Friction stir welding applications in industry. In Advances in Friction-Stir Welding and Processing; Elsevier: Amsterdam, The Netherlands, 2014; pp. 671-722.

17. Selamat, N.M.; Baghdadi, A.H.; Sajuri, Z.; Kokabi, A.H.; Junaidi, S. Effect of rolling on strength of friction stir welded joint of aluminium alloys. J. Kejuruter. 2018, 1, 9-15.

18. Baghdadi, A.H.; Selamat, N.F.M.; Sajuri, Z.; Kokabi, A.H. Effect of travel speed on quality and welding efficiency of friction stir welded AZ31B magnesium alloy. Int. J. Eng. Technol. (UAE) 2018, 7, 94-99. [CrossRef]

19. Baghdadi, A.H.; Sajuri, Z.; MohamadSelamat, N.F.; Omar, M.Z.; Miyashita, Y.; Kokabi, A.H. Effect of intermetallic compounds on the fracture behavior of dissimilar friction stir welding joints of $\mathrm{Mg}$ and $\mathrm{Al}$ alloys. Int. J. Miner. Metall. Mater. 2019. Accepted. [CrossRef]

20. Baragetti, S.; Urso, G.D. Aluminum 6060-T6 friction stir welded butt joints: Fatigue resistance with different tools and feed rates. J. Mech. Sci. Technol. 2014, 28, 11-14. [CrossRef]

21. Selamat, N.F.M.; Baghdadi, A.H.; Sajuri, Z.; Kokabi, A.H. Weldability and mechanical properties of dissimilar al-mgsi to pure aluminium and al-mg using friction stir welding process. J. Teknol. 2019, 81, 143-149. [CrossRef]

22. Threadgill, P.L.; Leonard, A.J.; Shercliff, H.R.; Withers, P.J. Friction stir welding of aluminium alloys. Int. Mater. Rev. 2009, 54, 49-93. [CrossRef]

23. Liu, X.; Xie, P.; Wimpory, R.; Li, W.; Lai, R.; Li, M.; Chen, D.; Liu, Y.; Zhao, H. Residual stress, microstructure and mechanical properties in thick 6005A-T6 aluminium alloy friction stir welds. Metals 2019, 9, 803. [CrossRef]

24. Behnagh, R.A.; Besharati Givi, M.K.; Akbari, M. Mechanical properties, corrosion resistance, and microstructural changes during friction stir processing of 5083 aluminum rolled plates. Mater. Manuf. Process. 2012, 27, 636-640. [CrossRef] 
25. Rao, D.; Huber, K.; Heerens, J.; Dos Santos, J.F.; Huber, N. Asymmetric mechanical properties and tensile behaviour prediction of aluminium alloy 5083 friction stir welding joints. Mater. Sci. Eng. 2013, 565, 44-50. [CrossRef]

26. Borrego, L.P.; Costa, J.D.; Jesus, J.S.; Loureiro, A.R.; Ferreira, J.M. Fatigue life improvement by friction stir processing of 5083 aluminium alloy MIG butt welds. Theor. Appl. Fract. Mech. 2014, 70, 68-74. [CrossRef]

27. Koilraj, M.; Sundareswaran, V.; Vijayan, S.; Koteswara Rao, S.R. Friction stir welding of dissimilar aluminum alloys AA2219 to AA5083-Optimization of process parameters using Taguchi technique. Mater. Des. 2012, 42, 1-7. [CrossRef]

28. Bintu, A.; Vincze, G.; Picu, R.C.; Lopes, A.B. Effect of symmetric and asymmetric rolling on the mechanical properties of AA5182. Mater. Des. 2016, 100, 151-156. [CrossRef]

29. Leal, R.M.; Loureiro, A. Effect of overlapping friction stir welding passes in the quality of welds of aluminium alloys. Mater. Des. 2008, 29, 982-991. [CrossRef]

30. Gabrielli, F.; Forcellese, A.; El Mehtedi, M.; Simoncini, M. Mechanical properties and formability of cold rolled friction stir welded sheets in AA5754 for automotive applications. Procedia Eng. 2017, 183, 245-250. [CrossRef]

31. Ozturk, F.; Sisman, A.; Toros, S.; Kilic, S.; Picu, R.C. Influence of aging treatment on mechanical properties of 6061 aluminum alloy. Mater. Des. 2010, 31, 972-975. [CrossRef]

32. Bayley, C.J.; Pilkey, A.K. Influence of welding defects on the localization behaviour of an aluminum alloy tailor-welded blank. Mater. Sci. Eng. 2005, 403, 1-10. [CrossRef]

33. Sato, Y.S.; Kokawa, H.; Enomoto, M.; Jogan, S. Microstructural evolution of 6063 aluminum during friction-stir welding. Metall. Mater. Trans. 1999, 30, 2429-2437. [CrossRef]

34. Hamed, J.A. Effect of welding heat input and post-weld aging time on microstructure and mechanical properties in dissimilar friction stir welded AA7075-AA5086. Trans. Nonferr. Met. Soc. China 2017, 27, 1707-1715. [CrossRef]

35. Pabandi, H.K.; Jashnani, H.R.; Paidar, M. Effect of precipitation hardening heat treatment on mechanical and microstructure features of dissimilar friction stir welded AA2024-T6 and AA6061-T6 alloys. J. Manuf. Process. 2018, 31, 214-220. [CrossRef]

36. Syarif, J.; Nakashima, K.; Tsuchiyama, T.; Takaki, S. Effect of solute copper on yield strength in dislocation-strengthened steels. ISIJ Int. 2007, 47, 340-345. [CrossRef]

37. Kozlov, E.V.; Koneva, N.A.; Popova, N.A. Grain structure, geometrically necessary dislocations and second-phase particles in polycrystals of micro-and mesolevels. Phys. Mesomech. 2009, 12, 280-292. [CrossRef]

38. Abbass, M.K.; Ameen, H.A.; Hassan, K.S. Effect of heat treatment on corrosion resistance of friction stir welded AA 2024 aluminum alloy. Am. J. Sci. Ind. Res. 2011, 2, 297-306. [CrossRef]

39. Lee, W.-B.; Kim, J.-W.; Yeon, Y.-M.; Jung, S.-B. The joint characteristics of friction stir welded AZ91D magnesium alloy. Mater. Trans. 2003, 44, 917-923. [CrossRef]

40. Verdier, M.; Janecek, M.; Brechet, Y.; Guyot, P. Microstructural evolution during recovery in Al-2.5\% Mg alloys. Mater. Sci. Eng. A 1998, 248, 187-197. [CrossRef]

41. Zhang, Y.; Liu, J.P.; Chen, S.Y.; Xie, X.; Liaw, P.K.; Dahmen, K.A.; Qiao, J.W.; Wang, Y.L. Serration and noise behaviors in materials. Prog. Mater. Sci. 2017, 90, 358-460. [CrossRef]

42. Härtel, M.; Illgen, C.; Frint, P.; Wagner, M. On the PLC effect in a particle reinforced AA2017 alloy. Metals 2018, 8, 88. [CrossRef]

43. Sarkar, A.; Chatterjee, A.; Barat, P.; Mukherjee, P. Chaotic Behavior of the Portevin-Le Chatelier Effect in Low Carbon Steel. In Proceedings of the National Conference on Nonlinear Science and Dynamics, Chennai, India, 1-4 Feburay 2006.

44. Yilmaz, A. The Portevin-Le Chatelier effect: A review of experimental findings. Sci. Technol. Adv. Mater. 2011, 12, 63001. [CrossRef]

45. Pink, E. Features of the Portein-Le Chatelier effect in a low carbon steel. Scr. Metall. Mater. 1994, 30, 767-768. [CrossRef]

46. Fu, S.; Zhang, Q.; Hu, Q.; Gong, M.; Cao, P.; Liu, H. The influence of temperature on the PLC effect in Al-Mg alloy. Sci. China Technol. Sci. 2011, 54, 1389-1393. [CrossRef]

47. Ling, C.P.; McCormick, P.G. The effect of temperature on strain rate sensitivity in an Al-Mg-Si alloy. Acta Metall. Mater. 1993, 41,3127-3131. [CrossRef] 
48. Dini, G.; Ueji, R.; Najafizadeh, A.; Monir-Vaghefi, S.M. Flow stress analysis of TWIP steel via the XRD measurement of dislocation density. Mater. Sci. Eng. A 2010, 527, 2759-2763. [CrossRef]

49. Baghdadi, A.H.; Rajabi, A.; Selamat, N.F.M.; Sajuri, Z.; Omar, M.Z. Effect of post-weld heat treatment on mechanical behaviour and dislocation density of FSWed Al 6061. Mater. Sci. Eng. A 2019, 754, 728-734. [CrossRef]

50. Malopheyev, S.; Kulitskiy, V.; Mironov, S.; Zhemchuzhnikova, D.; Kaibyshev, R. Friction-stir welding of an Al-Mg-Sc-Zr alloy in as-fabricated and work-hardened conditions. Mater. Sci. Eng. A 2014, 600, 159-170. [CrossRef]

51. Zhang, Z.; Yang, X.; Zhang, J.; Zhou, G.; Xu, X.; Zou, B. Effect of welding parameters on microstructure and mechanical properties of friction stir spot welded 5052 aluminum alloy. Mater. Des. 2011, 32, 4461-4470. [CrossRef]

52. Razavi, M.; Rahimipour, M.R.; Rajabi, A. Prenucleation effect on characterisations of synthesised nanocrystalline tungsten carbide via mechanical milling. Mater. Technol. 2013, 28, 145-154. [CrossRef]

53. Rajabi, A.; Ghazali, M.J. Quantitative analyses of TiC nanopowders via mechanical alloying method. Ceram. Int. 2017, 43, 14233-14243. [CrossRef]

54. Kalita, M.P.C.; Deka, K.; Das, J.; Hazarika, N.; Dey, P.; Das, R.; Paul, S.; Sarmah, T.; Sarma, B.K. X-ray diffraction line profile analysis of chemically synthesized lead sulphide nanocrystals. Mater. Lett. 2012, 87, 84-86. [CrossRef]

55. Deevi, S.; Deevi, S.C.; Verneker, V.R.P. Reactivities of aluminium and aluminium-magnesium alloy powders in polymeric composites. J. Mater. Sci. 1996, 31, 1043-1051. [CrossRef]

56. Salahi, E.; Rajabi, A. Fabrication and characterisation of copper-alumina nanocomposites prepared by high-energy fast milling. Mater. Sci. Technol. 2016, 32, 1212-1217. [CrossRef]

57. Sharma, C.; Upadhyay, V.; Dwivedi, D.K.; Kumar, P. Mechanical properties of friction stir welded armor grade Al-Zn-Mg alloy joints. Trans. Nonferr. Met. Soc. China 2017, 27, 493-506. [CrossRef]

58. Armstrong, R.W. Hall-Petch Relationship: Use in Characterizing Properties of Aluminum and Aluminum Alloys. In Encyclopedia of Aluminum and It Alloys; Totton, G.E., Tiryakioglu, M., Eds.; Taylor \& Francis Group: London, UK, 2016.

(C) 2020 by the authors. Licensee MDPI, Basel, Switzerland. This article is an open access article distributed under the terms and conditions of the Creative Commons Attribution (CC BY) license (http://creativecommons.org/licenses/by/4.0/). 